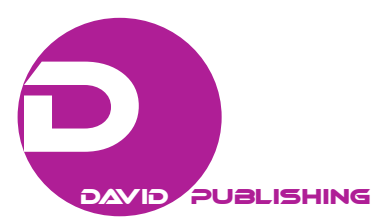

\title{
The Role of Venture Capital in Supporting the Development Process of Innovative Start-Ups: Evidence From the Italian Market
}

\author{
Anna Gervasoni, Francesco Bollazzi, Andrea Odille Bosio \\ Università Carlo Cattaneo-LIUC, Castellanza, Italy
}

\begin{abstract}
This research paper investigates the role of Italian venture capital in supporting innovative start-ups in their early-stage process, which is usually focused on the creation of a new product or the development of a new service. The aim of the study is to observe and assess the key economic features of innovative start-ups funded at the beginning of the early-stage by venture capital funds and thereafter analyze the level of development of target companies at four years since the capital injection. The sample of deals created to describe this dynamic process is composed by investments realized between 1996 and 2012 and, in this way, according to the chosen methodology, it is representative of Italian venture capital role and contribution in the years from 1996 to 2016. The authors used for their empirical study a proprietary database, Venture Capital Monitor- $\mathrm{VeM}^{\mathrm{TM}}$. Through the analysis of collected data, the paper describes the strategic importance of venture capital investments in early-stage opportunities both for target companies and the Italian socio-economic environment, and finds aggregate values of reference to quantitatively define the socio-economic outcome of this kind of operations. A final further contribution is provided by comparing the present results to the ones of two previous studies conducted by the authors.
\end{abstract}

Keywords: venture capital, start-up, early stage, Italy, Italian market, economic impact, development process

\section{Introduction}

Since inception in the Italian market, Venture Capital (hereinafter, also VC) funding strategy has always struggled to "take-off" and receive a high inflow of liquidity from investors. The causes for this shrunk sector are commonly often attributed to various risk-related concerns for this alternative investment asset class or to a more generic distrust in the Italian socio-economic entrepreneurial environment. On the other hand, it is possible to observe internationally a great appreciation for Italian entrepreneurialism and innovativeness. This paper represents an effort to rationally address this inconsistency and go deeper into the analysis of the dynamics involved in the Italian early-stage financing and in venture capital deals. Thus, the aim of this

\footnotetext{
Anna Gervasoni, full professor, SECS-P/08, Institute of Management, Università Carlo Cattaneo-LIUC, Castellanza, Italy.

Francesco Bollazzi, researcher, SECS-P/11, Institute of Management, Università Carlo Cattaneo-LIUC, Castellanza, Italy.

Andrea Odille Bosio, Ph.D. student, Institute of Management, Università Carlo Cattaneo-LIUC, Castellanza, Italy.

Correspondence concerning this article should be addressed to Francesco Bollazzi, Università Carlo Cattaneo-LIUC, Corso Matteotti 22, Castellanza 21053, Italy.
} 
research is to analyze if Italian venture capital funding and investment strategy model has been capable of producing positive effects on growth and innovation.

The paper initially proposes a literature review, intended to define the main concepts of venture capital and set the theoretical framework, and then a brief analysis of Italian market trend in the last decade, which is useful to better frame the research question. Thereafter, the paper presents and analyzes a sample of $74 \mathrm{VC}$ deals, over an initial database of 130 (that covers almost exactly the reference universe), which took place in Italy from 1996 to 2012. After assessing the sample representativeness of the overall market trend in those years, the authors analyze the balance sheet and the profit and loss of each target company at four years since the VC capital injection, in order to identify the contribution of venture capital in terms of value creation. This choice is mainly due to the average holding period of this kind of investments, which is usually between four and five years: According to this market evidence, the authors are so able to best evaluate the effects of venture capitalists' strategy and financing on participated firms.

Finally, the paper presents the results of the analysis by reporting the most significant socio-economic indicators from an aggregate point of view and discussing the final remarks drawn from these, also comparing them to the findings of two previous studies conducted by the authors themselves.

Consequently, the discussion of the analysis and the data reported assesses the real effects of $\mathrm{VC}$ on venture backed companies and its support to value creation, not only for target companies themselves, but also for the whole economic system.

\section{Literature Review}

Innovation and entrepreneurship in new businesses creation have always been established by literature as key elements for the economic growth of an economic system and for the creation of a competitive advantage (Ács, Audretsch, \& Strom, 2009; Audretsch, 2007; Audretsch \& Keilbach, 2004; Naudé, 2010). For this reason, scholars seek to analyze and understand these factors, while policy makers strive to stimulate them through the access to entrepreneurial finance (Cumming \& Fischer, 2012; Nahata, 2008; Wang, Wang, Ni, \& He, 2013; L. Wang \& S. Wang, 2012; World Bank, 2004). In this context, venture capital has always been detected as a key component both at a macroeconomic level (Bertoni, Colombo, \& Quas, 2015; Cumming, Johan, \& Zhang, 2014; Cole, Cumming, \& Li, 2016; Samila, 2012) and at a microeconomic one (Bonini, Alkan, \& Salvi, 2012; Elango, Fried, Hisrich, \& Polonchek, 1995; Hargadon \& Kenney, 2012; Humphery-Jenner \& Suchard, 2013).

How is it possible to define venture capital? European and American literature defines venture capital as investments aimed at stimulating new entrepreneurial activities (financing for start-up, early-stage financing) as well as further developing already existing businesses (financing for development, expansion financing), within the wider context of private equity investments, representing the multitude of investments carried out by institutional investors in risk capital, who are internationally referred to as private equity and venture capital operators (Gompers \& Lerner, 2004; Gervasoni \& Sattin, 2015).

With particular reference to early-stage financing and the process of enterprise creation, the various steps a new venture must progress through have been identified as the following: seizing an opportunity, formalizing the idea, safeguarding from possible imitations, constructing a team, raising financial resources, bringing about the start-up, launching the new product. Without entering into deep analysis of the details in each phase, it is possible to affirm that, be it to a different extent for each phase, venture capitalists have to play an important 
role in all the above mentioned activities. During early-stage deals, a future entrepreneur often needs more help than just a financial contribution and aid in developing a clearer definition of his business idea and entrepreneurial scheme; he or she also needs to be advised about his or her relative competitiveness on the market. Thus, one can say there are various benefits a future entrepreneur can draw from a relationship with a venture capitalist.

Finally, many studies in Italian and international literature have highlighted how venture capitalism plays an important role in the financial markets by supplying new financial assets to unquoted enterprises with great potential for development. The impact such investors have on the market can be seen in statistics for employment, innovation and business efficiency, measured in accordance with various ratios (Hellmann \& Puri, 2000; Romain \& van Pottelsberghe, 2003; Gompers \& Lerner, 2004; Bollazzi \& Gervasoni, 2006; 2013). Thus, there is evidence to the effect that venture capitalism contributes in a positive way to employment and economic performance. In fact, these studies have demonstrated how the entry of a venture capitalist raises the economic and financial performance of a company above the average level of its market, thereby also benefiting quality of governance, research and development expenses, employment and investment growth.

\section{Research Question}

As previously described, the literature review assesses the phenomenon of venture capital and its positive effects according to several different rationales and indicators used for the different analysis.

This research focuses on the analysis of start-ups growth and development in a four-year investment cycle starting from the risk capital injection, in order to understand and underline the socio-economic effects due to the capital increase. For this reason, the research follows the analysis framework set by studies as the ones of Davila, Foster, and Gupta (2003) and Gervasoni and Bollazzi (2006; 2013), which use both a descriptive and a quantitative approach.

Thus, the research question can be framed as the following: Has venture capital funding, with its investment model, been able to produce positive effects on the socio-economic growth of venture backed companies?

In addition to the question statement, it appears important to highlight two really important characteristics of the environment which will be studied: First of all, for what concerns the relationship between the firm and the venture capitalist, it is fundamental to underline that this kind of deal is a really high-risk investment, as it is confirmed by academic and professional literature; moreover, regarding to the context, it is necessary to notice a peculiar feature of the Italian market, specifically the shrunk total market capitalization and number of operations in relation to other comparable European countries (as represented in Figure 1).

So, the paper intends to investigate the actual value creation process carried out by Italian venture capitalists, by identifying the real contribution of $\mathrm{VC}$ players and measuring in absolute terms the extent to which their presence in the risk capital of innovative start-ups may influence and drive the firm's initial stage of growth. This kind of measurement is performed through the selection of some relevant company's balance sheet key figures, as explained in the following methodological section, and also a non-financial indicator that is the contribution to employment (Gompers \& Lerner, 1999). 


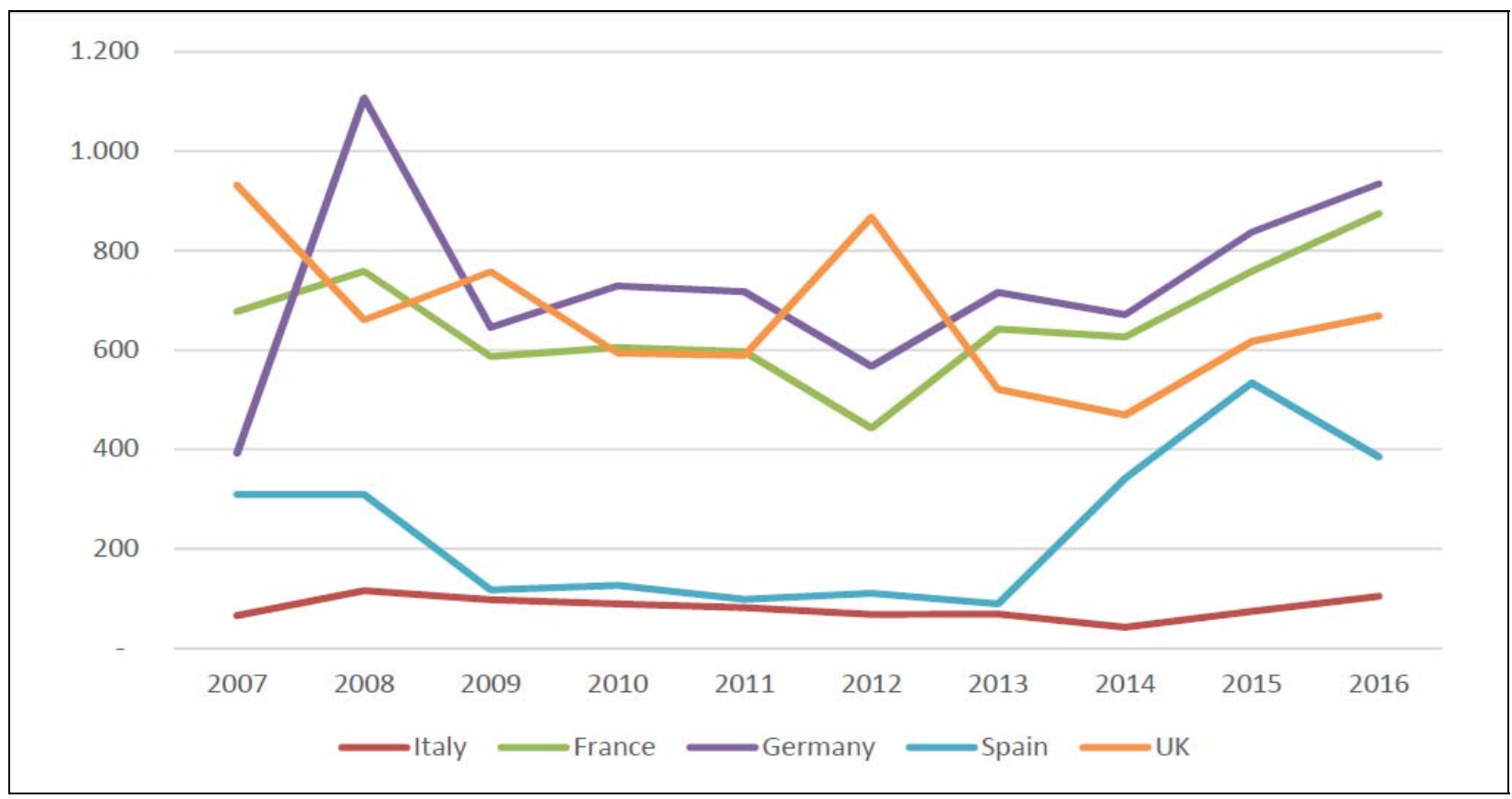

Figure 1 . Total amount invested in venture capital by country $(€, \mathrm{mln})^{1}$.

\section{Methodology}

\section{Data Sample}

After the literature review, the ad hoc empirical research started with the construction of a representative database of deals realized in the Italian market. In order to complete this step, the main source of data has been identified in a proprietary database, Venture Capital Monitor- $-\mathrm{VeM}^{\mathrm{TM}}$ (hereinafter, also $\mathrm{VeM}^{2}$ ), which is based on public information and published yearly at University Carlo Cattaneo-LIUC. This dataset is particularly suitable because it ensures a full specific coverage of the whole Italian venture capital market, for what concerns initial investments ${ }^{3}$.

Moving from the information included in VeM, the operations were filtered by year of investment to create a timeframe of 16 years, from 1996 to 2012 (as previously mentioned, in order to evaluate the economic impact of each investment four years after the VC capital injection), hence covering different phases of the Italian economic cycle, so including the "Dot-com Bubble" and the "Great Recession" period. The rationale behind the choice of such a long period to be considered is the wish to obtain an analysis and, consequently, final remarks about the role of venture capital excluding any possible sample selection bias due to specific macroeconomic phenomena. In this way, approximately 300 deals were detected.

Additionally, the operation taken into consideration were just those one having a vintage year equal to zero or, at most, one ${ }^{4}$, in this way considering only companies which have received risk capital from an

\footnotetext{
${ }^{1}$ Country data retrieved respectively from: AIFI-PwC, AFIC, BVK, ASCRI, BVCA.

${ }^{2}$ Venture Capital Monitor-VeM ${ }^{\mathrm{TM}}$ is a proprietary database which is published annually by University Carlo Cattaneo-LIUC. It takes into consideration only venture capital deals, exclusively through the use of public data sources. Nowadays, it counts more than 500 investments realized between 1996 and 2017.

${ }^{3}$ Initial investments are only first round financing.

${ }^{4}$ This means that the authors have considered only deals in which the capital injection has happened exactly in the year of the firm's foundation or, at most, in the following one.
} 
institutional investor at the very beginning of its foundation. This has been done in order to focus the analysis on the investments in which the contribution of a venture capitalist could have the highest effects on business development and, at the same time, to exclude exogenous business dynamics, usually more frequent in later VC rounds that may have influenced the results.

The application of this second requested characteristic brought the authors to obtain a database of 130 deals. For each of them, the authors themselves started the process of data collection, as described in the following section.

\section{Data Collection}

The initial database showed a set of 130 identified deals, representing all the investments conducted in the chosen period and mapped with public available information. It was subsequently integrated with the economic data of target companies at four years from the initial financing. As already declared, this choice is mainly due to the average holding period of this kind of investments, which is usually between four and five years, but also identifying the first three years in the life cycle of a firm as the most critical period for the company survival, as a sort of first "natural selection" made by the market.

For this part of the data collection, the information was gathered from the annual report of each company, through AIDA Database edited by BvD, and integrated through further public sources of information such as newspapers, industry and financial journals and websites of VC funds.

Finally, 56 companies had to be excluded from the analysis due to the lack of data. The main reasons of this evidence may be found in some write-offs, in the involvement of target companies in M\&A processes or in the choice to change the country for the headquarter. For the remaining 74 operations, the data-entry has been successful and so these deals constituted the authors' final dataset for the empirical study.

As a final summary, with reference to each investment, collected information were about:

- a framing of the phenomenon under investigation, in terms of temporal, geographic, and sectoral distribution;

- quantitative evidences, based on financial statement indicators and performance ratios (Revenues, EBITDA, EBT, Added Value, Fixed Assets, Net Worth and employees number $)^{5}$, with the aim of identifying the economic impact generated by the presence of an institutional investor in the shareholding structure of a company.

Therefore, the final results have the aim of framing the average structure and performance of those Italian start-ups companies which are characterized by their choice to team up with a venture capitalist since their establishment.

\section{Analysis Results}

The analysis of the empirical data is divided into two main parts. The first part focuses on the description about some qualitative characteristics of the sample, in this way also checking its consistency and representativeness. The second part aims to analyze the economic data and draws specific conclusions regarding the economic impact of the venture capital activity on innovative start-ups and Italian economic system in general.

\footnotetext{
${ }^{5}$ A detailed description of the chosen indicators is included in the following section about analysis results.
} 


\section{Descriptive Statistics of the Sample}

The first information to be analyzed regarding the sample is its distribution over the timeframe taken into consideration. In this sense, the sample consistently represents the market trends, as reported by VeM annual reports and by $\mathrm{AIFI}^{6}$ annual statistics. Taking a look at the data, it emerges with a clear evidence, and this constitutes a further factor of coherence between the universe and the sample, how the two-year period 1999-2000 has constituted a moment of real intense activity for the market, which has usually remained on lower volumes in the other years chosen for the constitution of the sample, although presenting a certain vivacity with specific reference to 2005 and an acceleration starting from 2009. The two years 2001 and 2007 were not considered only for the previously explained lack of data, for what concerns economic indicators.

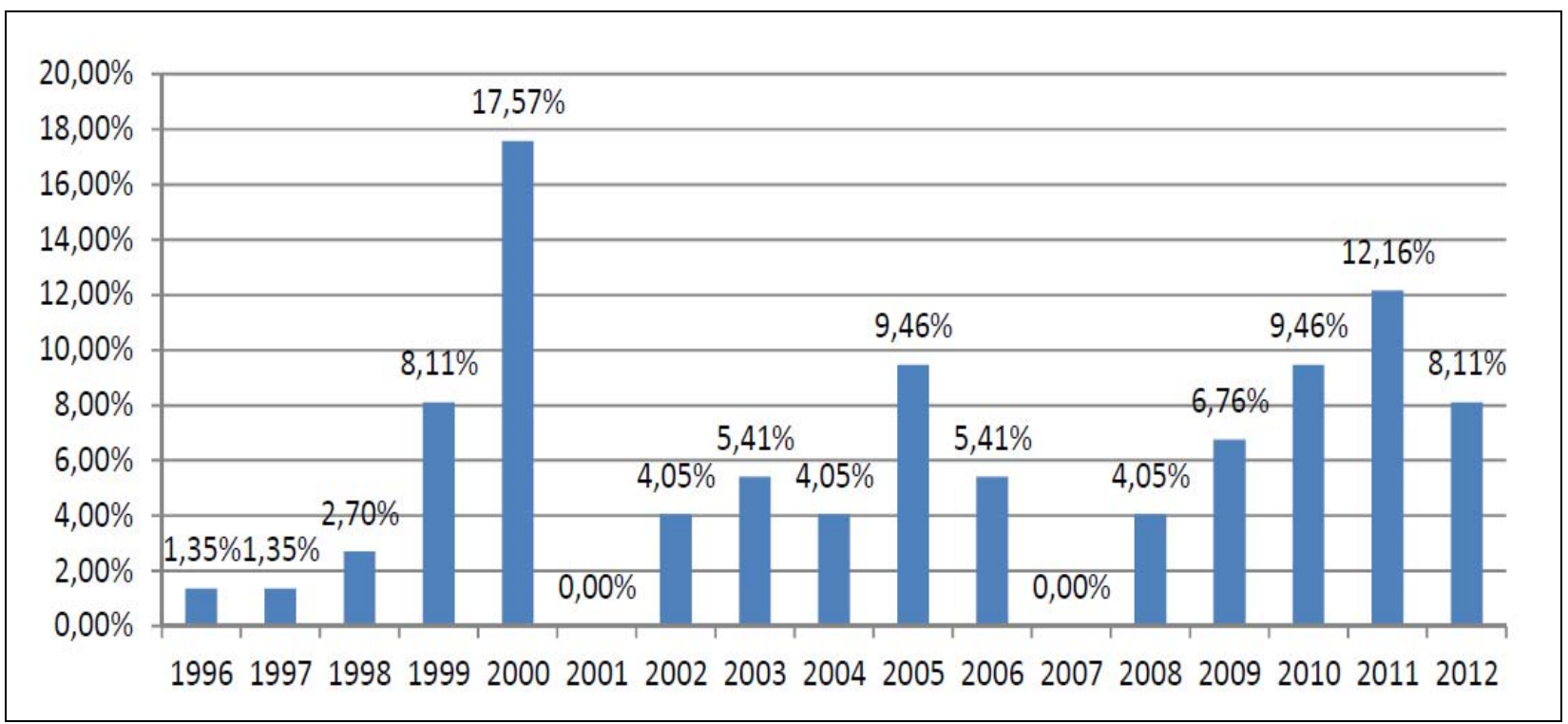

Figure 2. Temporal distribution of the sample (personal elaboration).

Moving to the description of the sample in relation to the operators' activity, from Figure 3 it is possible to notice how monitored deals present a relatively high level of concentration, with $50 \%$ of them conducted by six venture capitalists, with an average of 2.83 operations each. These data were checked with those presented by AIFI with reference to the whole market, finding a confirmation about the representativeness of the dataset ${ }^{7}$.

Going deeper into the analysis concerning investors, it is possible to detect the presence of highly specialized players in the financing of the start-up phase of a company. They are able to carve out a leading role in the market, considering the fundamental role, in this activity, of skills acquired thanks to their own track record and the related experience curves.

Figure 3 shows what just stated. The name of VC players has been omitted, but all the leading investors which result from the analysis are fully specialized in this specific kind of risk capital investments.

\footnotetext{
${ }^{6}$ AIFI is Italian Private Equity and Venture Capital Association (www.aifi.it).

${ }^{7}$ In AIFI reports, during the same historical period, the first five most important operators are able to cover an average of more than $50 \%$ of the whole market of venture capital in Italy.
} 


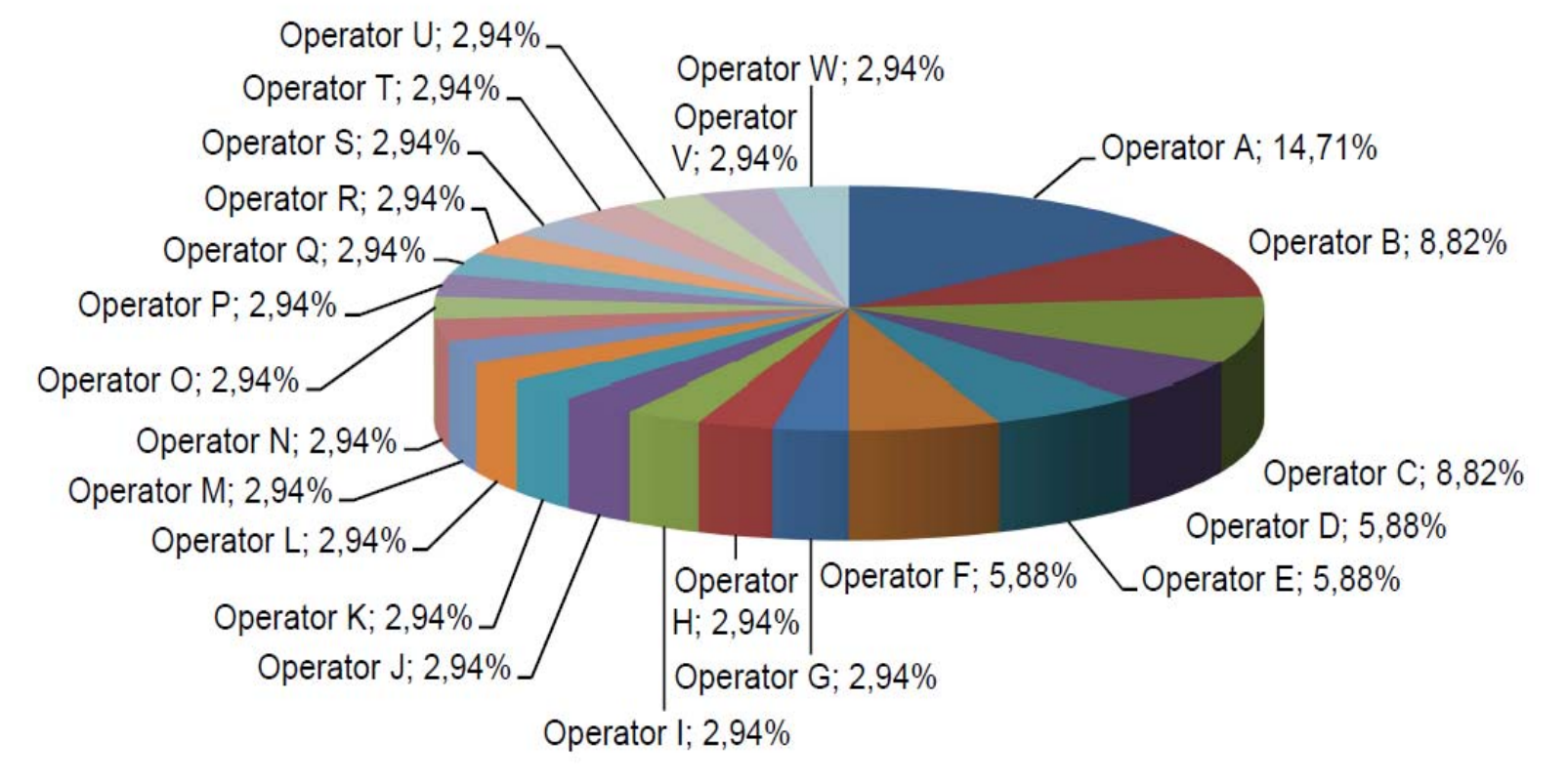

Figure 3. Distribution of the sample by number of operations for each venture capitalist (personal elaboration).

Other two interesting aspects of the sample distribution may be found by inquiring the geographical region where target companies have been established and the different industries in which they operate in.

For what concerns geographical distribution, the built sample essentially confirms all the average statistics of the venture capital industry. Northern Italy is confirmed to be as the territorial area on which the attention and the activity of VC players are more intensive. The analysis reflects the common trend to concentrate investments in the most industrialized regions (in particular, only Lombardy represents approximately $37 \%$ of the whole market, gathering nearly $43 \%$ of invested resources). Figure 4 shows these evidences in detail.

Despite this, the remaining target companies are distributed in many other regions, confirming the evidence that investors, except for the ones who are strongly localized and rooted in their geographical area, have as main drivers the potential of the business idea and the quality of the firm's management.

Furthermore, it should be noted that there is a satisfactory attention devoted by VC players to the centre and the south of our country. Consequently, there is an interesting contribution of this geographical area on the dynamics of the analyzed market. In fact, the number of investments attributable to the Italian "Mezzogiorno" is approximately $20 \%$ of the whole market, with peaks close to $30 \%$ if the attention is restricted to the three-year period 2011-2013 (corresponding to the government measure "Fondo High Tech per il Mezzogiorno", promoted to sustain venture capital in this area).

From an industrial point of view, the companies were classified through the use of the SIC Code ${ }^{8}$. In this regard, there is a clear predominance of investments in companies belonging to innovative sectors, characterized by the use of new technologies (high tech) or, in any case, by the introduction of significant product or process innovations. In particular, about $34 \%$ of companies operate in industries linked to

\footnotetext{
${ }^{8}$ SIC (Standard Industrial Classification) Code represents the sectoral classification of reference at international level (www.siccode.com).
} 
Information and Communication Technology, more than 13\% in the neighboring Media and Communications segment, approximately $11 \%$ in professional services, a significant $15 \%$ in the fields related to health and pharma. It is also possible to underline a contribution from the more traditional industrial sectors.

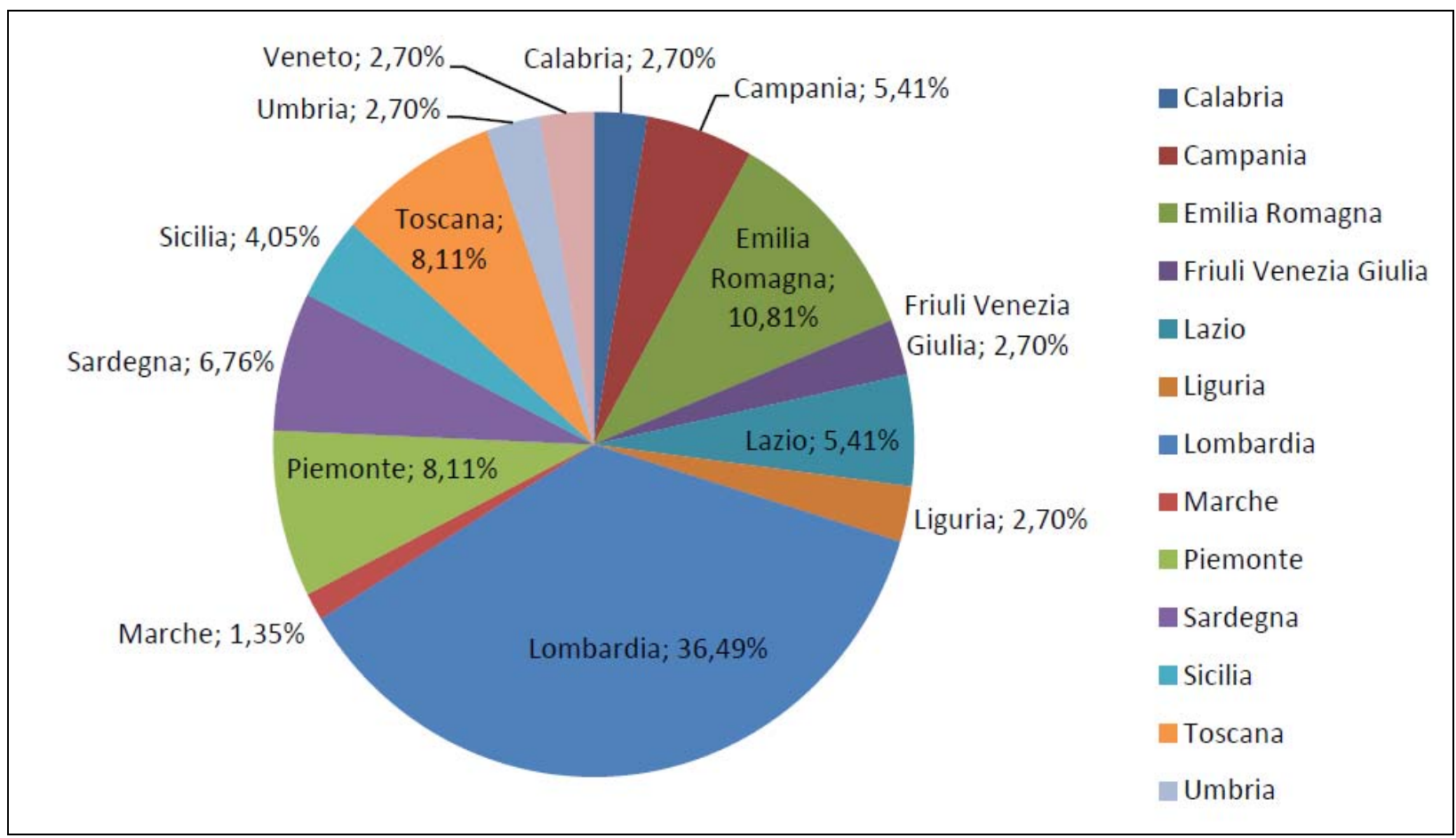

Figure 4. Geographical distribution of the sample (personal elaboration).

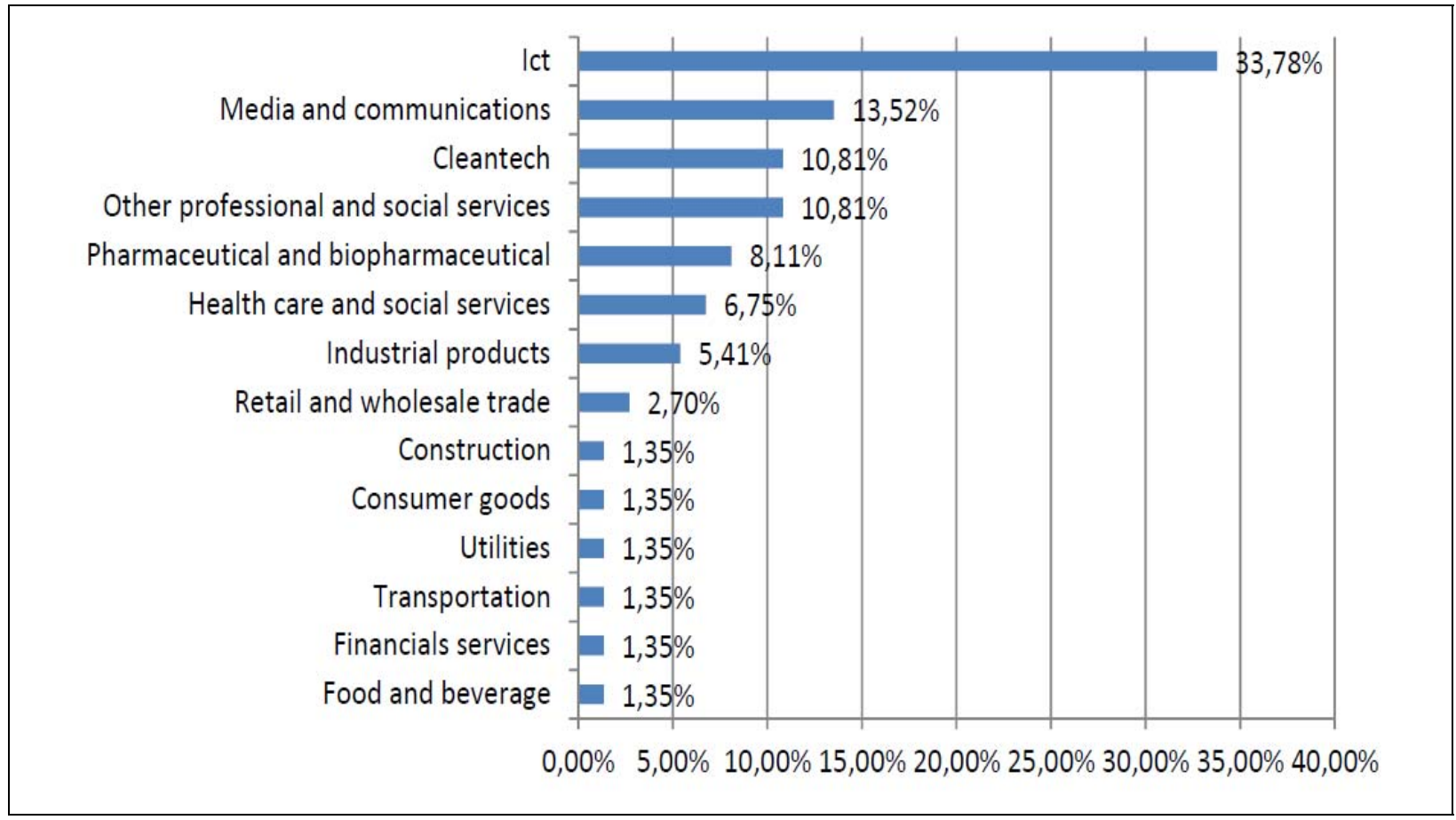

Figure 5. Distribution of the sample by industry (SIC Code) (personal elaboration). 
Another real interesting evidence, which directly confirms the role of venture capital in supporting innovation, is the presence of deals in patent-intensive industries, such as the pharmaceutical and biopharmaceutical one.

\section{The Economic Impact}

In this part of the sample description and analysis, the authors investigated the main economic effects produced by VC investments, obtained after the study of the balance sheets data. As mentioned in the methodology explanation, the data obtained by this sample are relevant in showing the result of target companies that reached the landmark of four years of activity, in this way proving the potential of their business proposal.

As just declared during the explanation of the research methodology, economic performance variables were analyzed, such as Revenues ${ }^{9}$, EBITDA $^{10}$, Pre-tax Profit $(E B T)^{11}$, and Added Value ${ }^{12}$. Furthermore, some other indicators were taken into consideration: They were considered to be significant from a patrimonial point of view, such as Net Fixed Assets ${ }^{13}$ and Net Worth ${ }^{14}$, as well as from an occupational point of view, such as the number of employees ${ }^{15}$. Thus, the authors proceeded to the study of the annual reports and to the elaboration of the data obtained from them, with the aim of reaching up to significant synthesis evidences.

For each of these indicators, statistic indexes were calculated and reported in Table 1.

In the following discussion, the indicators are conceptually divided in two subgroups to better understand the flow of the assessment and discussion. The first subgroup relates to the analysis of performance indicators of target companies and comprehends Revenues, EBITDA, EBT, and Added Value. The second subgroup comprehends the remaining assets indicators and the indicator of employees number.

Table 1

Sample Summary for Economic Variables $(* €$, th) (Personal Elaboration)

\begin{tabular}{lllllllll}
\hline & Revenues* & EBITDA* & EBT* & $\begin{array}{l}\text { Added } \\
\text { value* }\end{array}$ & $\begin{array}{l}\text { Net fixed } \\
\text { assets* }\end{array}$ & Net worth* & Employees \\
\hline Mean & $3,134.5$ & -784 & -834 & 9,665 & 26,158 & 10,498 & 35 \\
Median & 1,570 & 77 & -12 & 592 & 1,026 & 2,083 & 16 \\
Max & 24,901 & 3,025 & 3,082 & 15,761 & 68,379 & 117,566 & 362 \\
Min & 1 & $-26,400$ & $-32,061$ & $-20,694$ & -29 & -673 & 1 \\
\hline
\end{tabular}

Performance indicators. The analysis by turnover classes shows that the morphology of analyzed companies is quite heterogeneous, with the presence of both really small and medium-sized companies, with revenues between three and six million $(19 \%)$ or even higher $(17 \%)$. The distribution of the sample is shown in

\footnotetext{
${ }^{9}$ This means the total value of production, therefore the sum of sales revenues and other marginal forms of revenue. It is called also turnover.

${ }^{10}$ This refers to the gross operating margin from operations (Ebitda, Earn before interest, taxes, depreciations and amortizations).

${ }^{11}$ The authors mean the final value of the income statement, net of extraordinary items, but gross of tax. It was preferred to refer to the pre-tax result, rather than to net profit, in order to neglect the possible distortive effect generated by the fiscal aspect, frequent in the first years of entrepreneurial activity.

12 The authors mean the difference between revenues, as defined above, and the purchase cost of raw materials, the cost for services and the cost for the enjoyment of third party assets.

${ }^{13}$ This refers to all tangible, intangible and financial assets, net of the respective depreciation funds.

${ }^{14}$ This means the value resulting from the sum of the share capital, reserves and retained earnings.

${ }^{15}$ This means the sum of executives, managers, employees, and workers permanently present in the company.
} 
Figure 6. The range with the highest frequency is the one presenting a turnover between one and three million and, in this sense, the value returned by the computation of the mean of the sample, equal to about 3.1 million, appears to be the most indicative of the typical dimension of the investigated firms.

Then, two additional parameters, EBITDA and EBT, were examined (Figures 7 and 8). In detail, it may be noticed how respectively $64 \%$ and $45 \%$ of the companies in the sample presents a positive performance, while on the contrary all the other companies show negative results for what concerns these indicators, even if, and it is really meaningful to clarify this in order to fully understand the evidence of the analysis, very restrained in almost all cases.

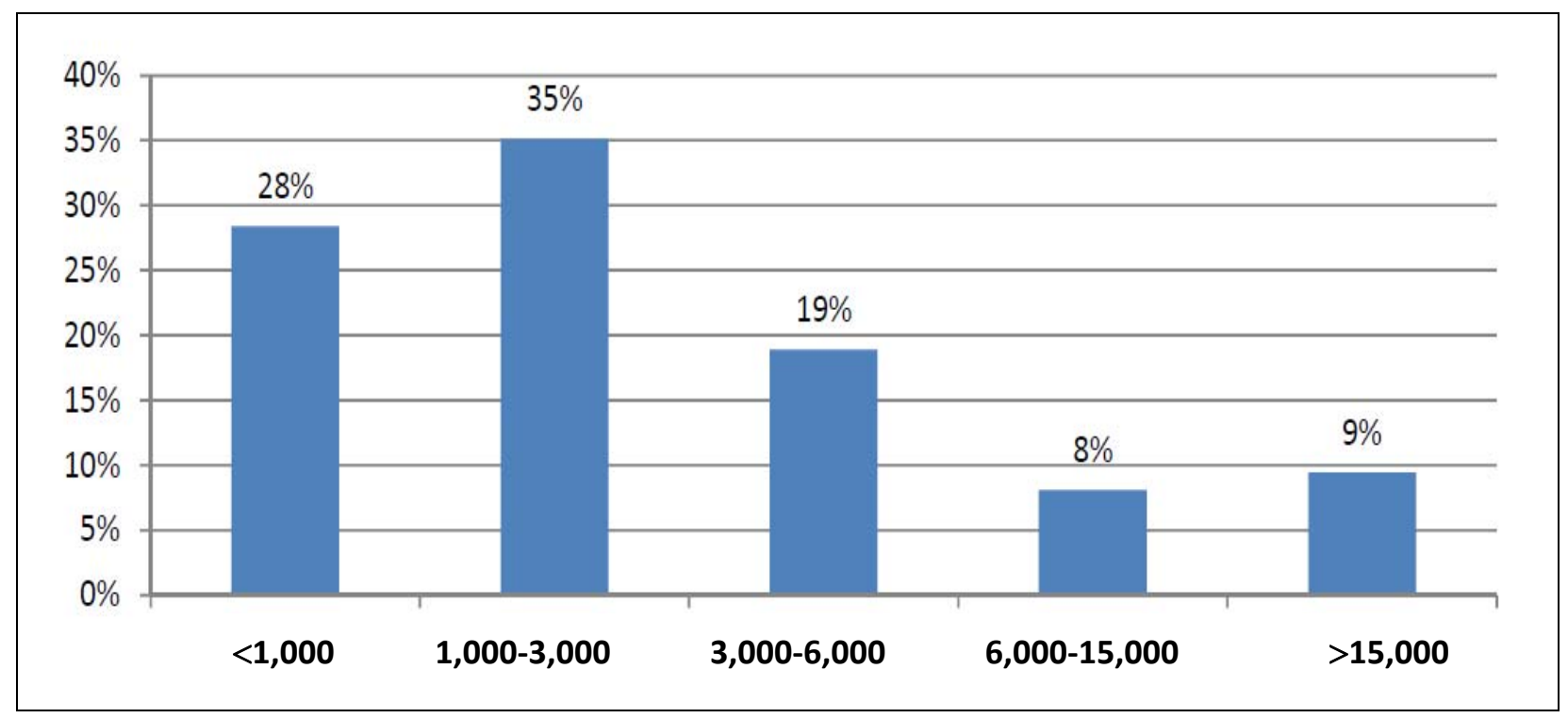

Figure 6. Distribution of the sample by classes of revenues $(€$, th) after four years of operating activity (personal elaboration).

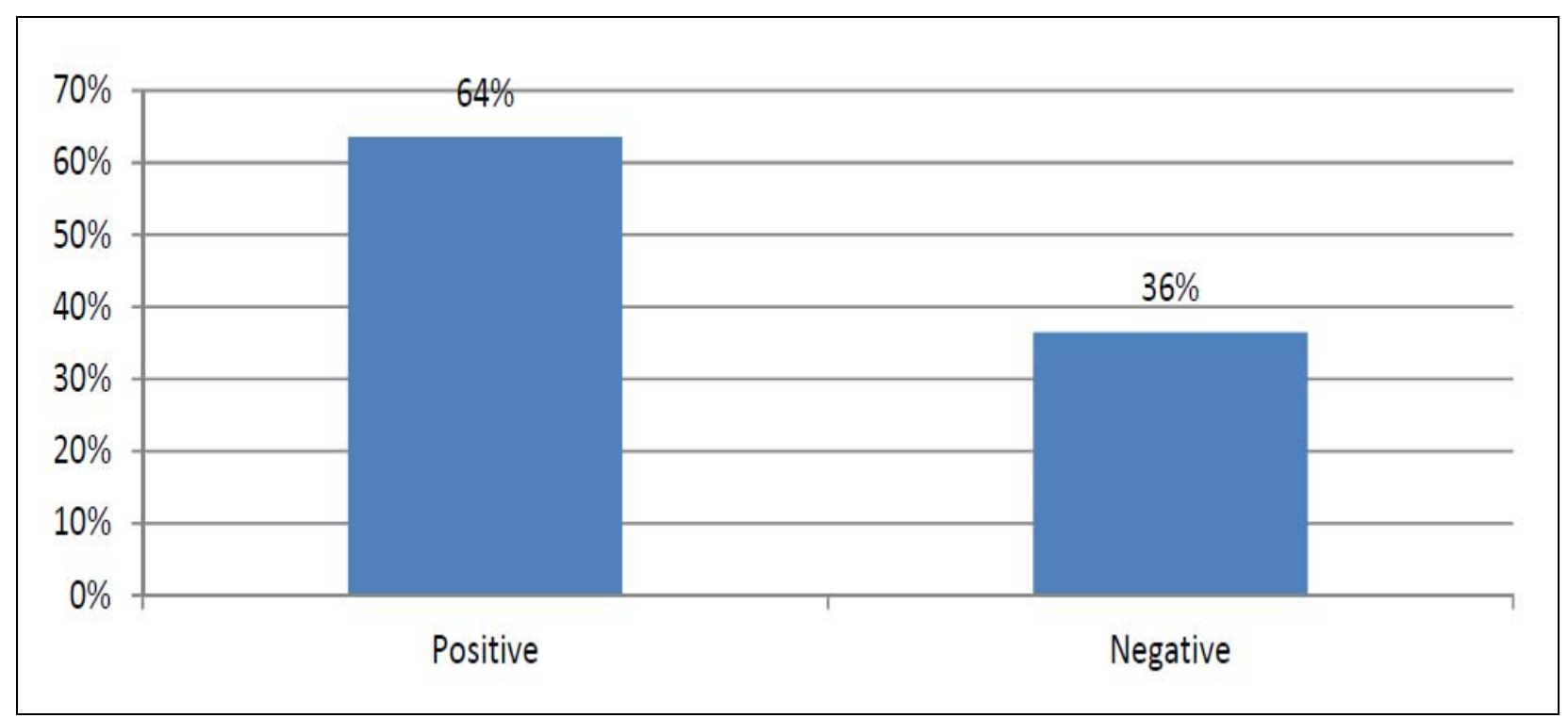

Figure 7. Distribution of the sample by EBITDA after four years of operating activity (personal elaboration). 


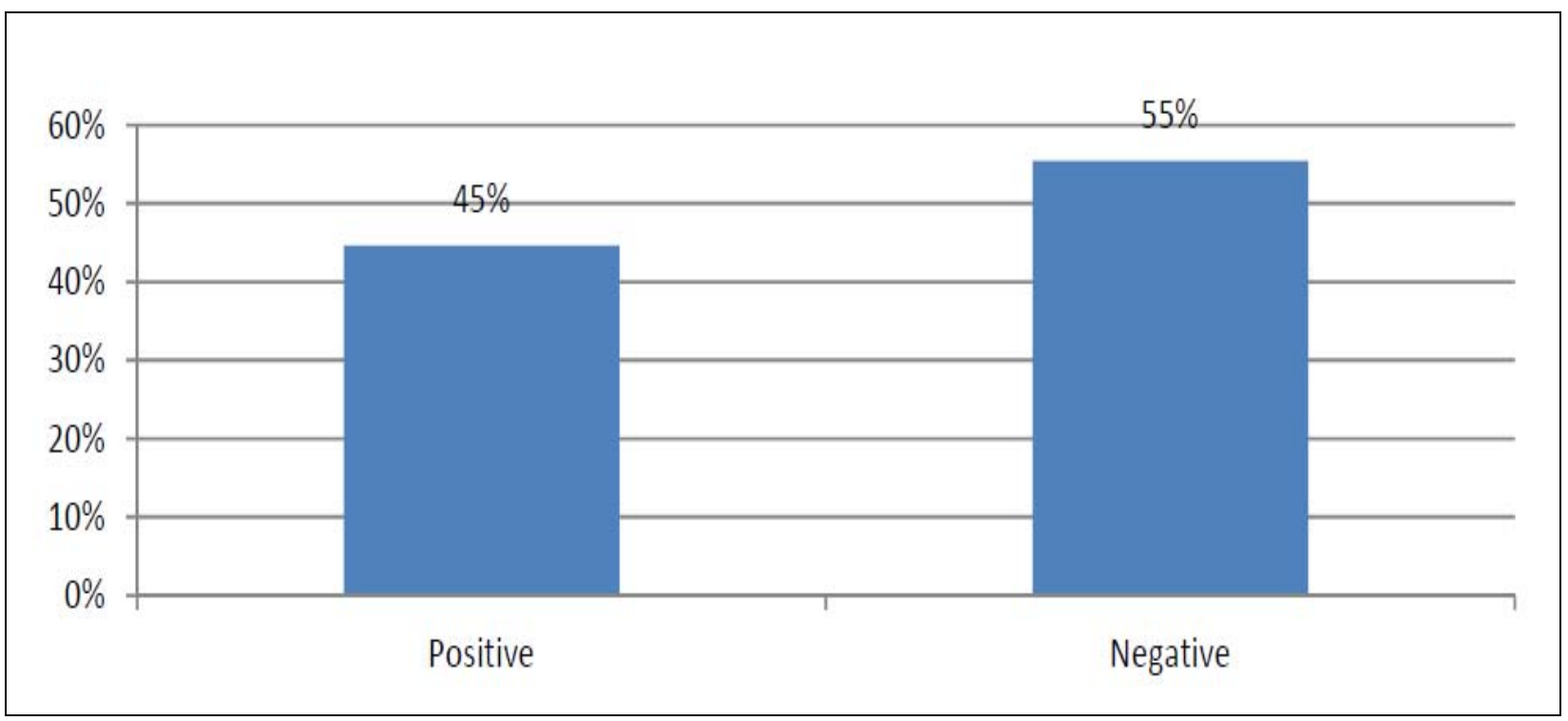

Figure 8. Distribution of the sample by EBT after four years of operating activity (personal elaboration).

The sample is therefore characterized by the presence of many companies which are already able to present positive economic performance since the start, by a group of companies with negative results that are absolutely restrained and finally by a few realities with badly negative results and so probably affected by chronic problems at a structural level.

Moreover, it is absolutely physiological, as it can be confirmed by the statistics ${ }^{16}$ relating to VC industry, the incidence of write-offs in the field of early stage financing, which is around $20 \%$ in Italy and is only slightly more contained also in Europe and in the United States. This finding has its essential explanation in the high risk/return profile which characterizes this particular kind of investment.

The evidences emerged from the empirical analysis, therefore, are not completely unexpected and don't lead automatically to a negative judgment on the status of the analyzed companies which shows negative indicators. In support of this thesis, it is possible to bring some useful considerations, which are able to reinforce the simple observation, however certainly true that some target companies may not have yet fully developed their business after four years of operating activity.

First of all, if we focus the attention on EBT results, it is necessary to remember that, since these companies are still in the early stage of their life cycle, it is clear that this indicator suffers and discounts the effect of the depreciation plans related to the first round of investments, usually rather expensive, both in an absolute point of view and sometimes also in relation to the volume of the business. Furthermore, the negative effect produced by financial charges coming from the possible recourse to debt, necessary to finance the investments themselves as well as the beginning of the activity, must also be taken into consideration. In this sense, the presence of $45 \%$ of companies able to present positive results is particularly significant from an economic perspective.

If we turn the attention to EBITDA, the interesting evidence comes from the almost always contained dimension of the negative results recorded by the companies in the sample, as well as from the survival of these

\footnotetext{
16 Sources: AIFI, EVCA (European Private Equity and Venture Capital Association), NVCA (National Venture Capital Association).
} 
companies on the market (it is important to remember, in this regard, that the sample was analyzed at the end of the fourth year of activity). Obviously, this remark doesn't imply that a positive judgment can be extended to all the observations of the sample, as there are also situations of really clear structural difficulties. It is possible, however, to underline how $64 \%$ of venture backed companies have already reached the break even point, as shown in the previous chart. In addition, a careful reading of the single financial statements demonstrates that a further $15 \%$ is close to it, with absolutely marginal negatives results. It should be remembered, concerning this remark, how the literature concerning the genesis of new business initiatives considers the achievement of break even as one of the most critical points, not only in an absolute sense (it is clear, in fact, that an activity which is not able to generate resources is not sustainable in a long-term period), as well as in relation to the time necessary to achieve it.

In support of what has just been stated, it is possible to report the study carried out with reference to the generated added value, chosen for the present analysis as an indicator of the "quality" and sustainability of the business.

What emerged is represented graphically in Figure 9, from which the authors obtain a significantly different sample distribution compared to the previous two. About $82 \%$ of the total enterprises are structured, even with different levels of performance, to carry out an activity which is able to create value, a signal of a business with a great probability to reveal itself as sustainable and consistent in the long-term period. This evidence consolidates and supports what was previously stated with reference to the negativity of EBITDA and EBT of some companies composing the sample.

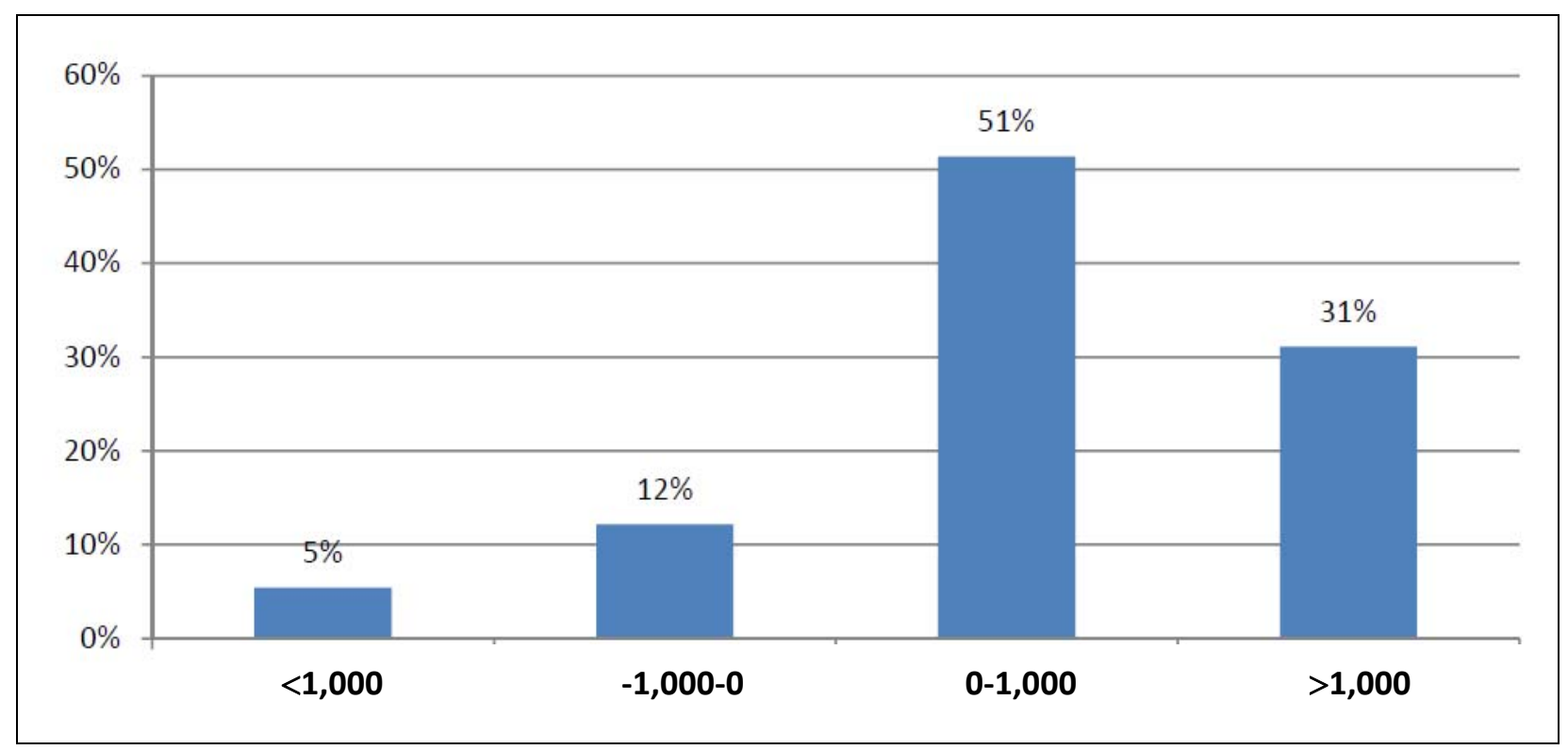

Figure 9. Distribution of the sample by classes of Added Value $(€$, th) after four years of operating activity (personal elaboration).

From this final consideration, in particular, there are two important confirmations: the fundamental role played by the deal flow process conducted before realizing each VC investment; the great capability of VC funds of assessing a business model or a project proposal, in order to choose only the best ones.

Patrimonial indicators and employees. The second part of the analysis is related to the assessment of the companies' patrimonial structure and to the evaluation of the occupational impact. In this regard, Figure 10 
shows the distribution over classes of the first chosen parameter, which is Net Fixed Assets, while Figure 11 reports the Net Worth classes. Taking into consideration these two parameters and linking them with the previous sectoral distribution of target companies, it is possible to underline how in general venture backed firms don't require particularly huge capital investments in fixed assets, due to the fact that they generally don't involve capital intensive sectors. A deeper analysis of the dataset is allowed to notice a sort of change in this evidence, if we consider only the most recent period (in particular, the last five years): Gradually, it is possible to observe an increasing effort by venture capitalists to support greater investment plans in their participated companies. This evidence will be really useful in the following final remarks of this research paper.

The last parameter relates to the social aspect of a $\mathrm{VC}$ investment and takes into consideration the number of employees of target companies. In Figure 12, it is represented the distribution by classes of employees number. From this, it is possible to show how investigated firms are, after four years of operating activity, prevalently small and medium enterprises with an average of 35 employees. This evidence represents a really meaningful occupational data, considering the difficulty of each start-up process and the structural difficulties showed by the job market in Italy in many recent years.

\section{Discussion and Comparison}

In order to be able to translate the results emerged during the analysis in a meaningful synthesis, it seems useful to propose some qualitative and quantitative considerations, in order to better clarify the real impact generated by the investment activity of VC players, with reference to the financing of start-up firms. In this sense, it seems possible to carry out two orders of reflections: the first, concerning the profitable relationship between entrepreneur and venture capitalist; the second one, which is able to simply determine, from a quantitative point of view, the results of the cooperation between the entrepreneur and an institutional investor.

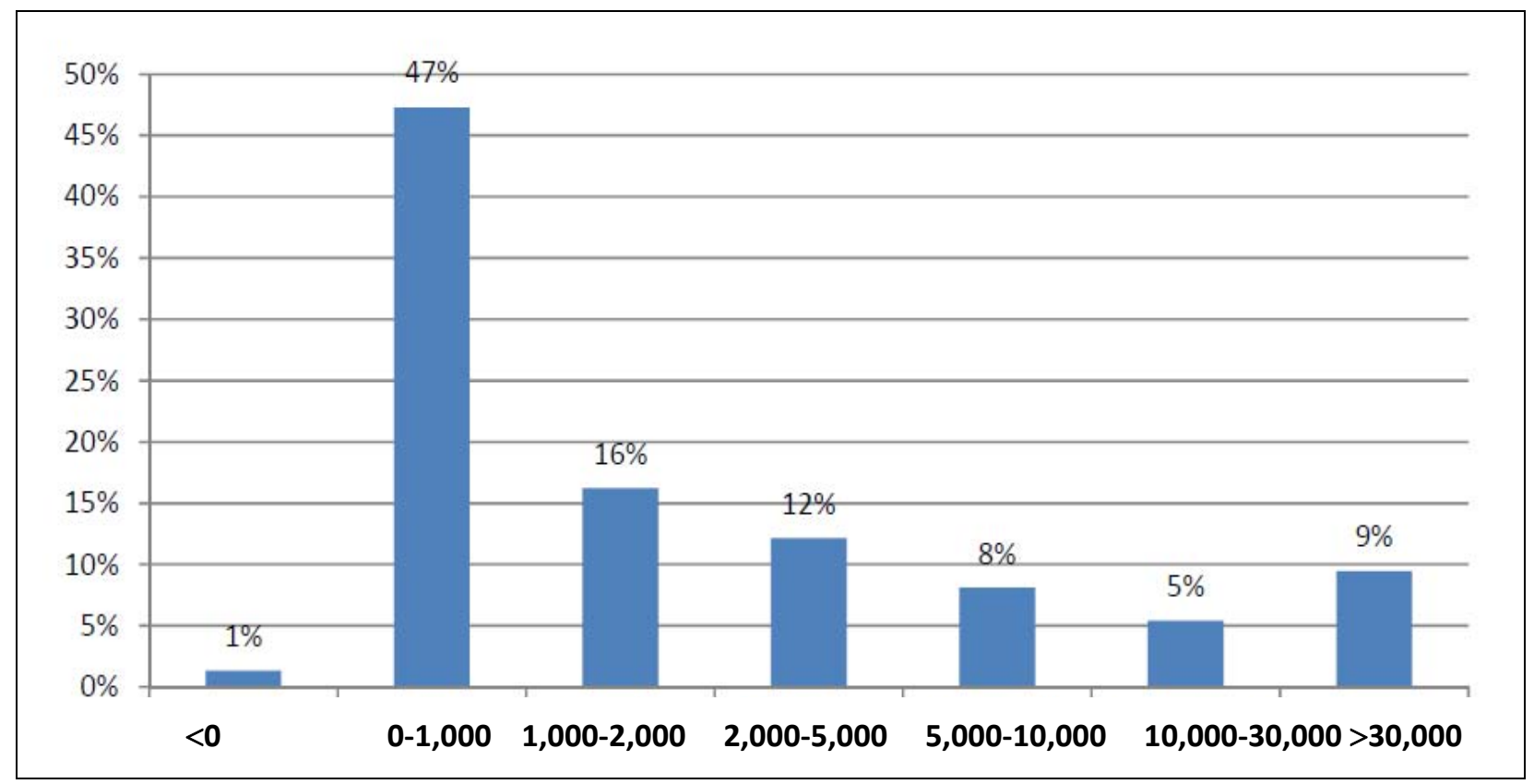

Figure 10. Distribution of the sample by classes of Net Fixed Assets $(€$, th) after four years of operating activity (personal elaboration). 


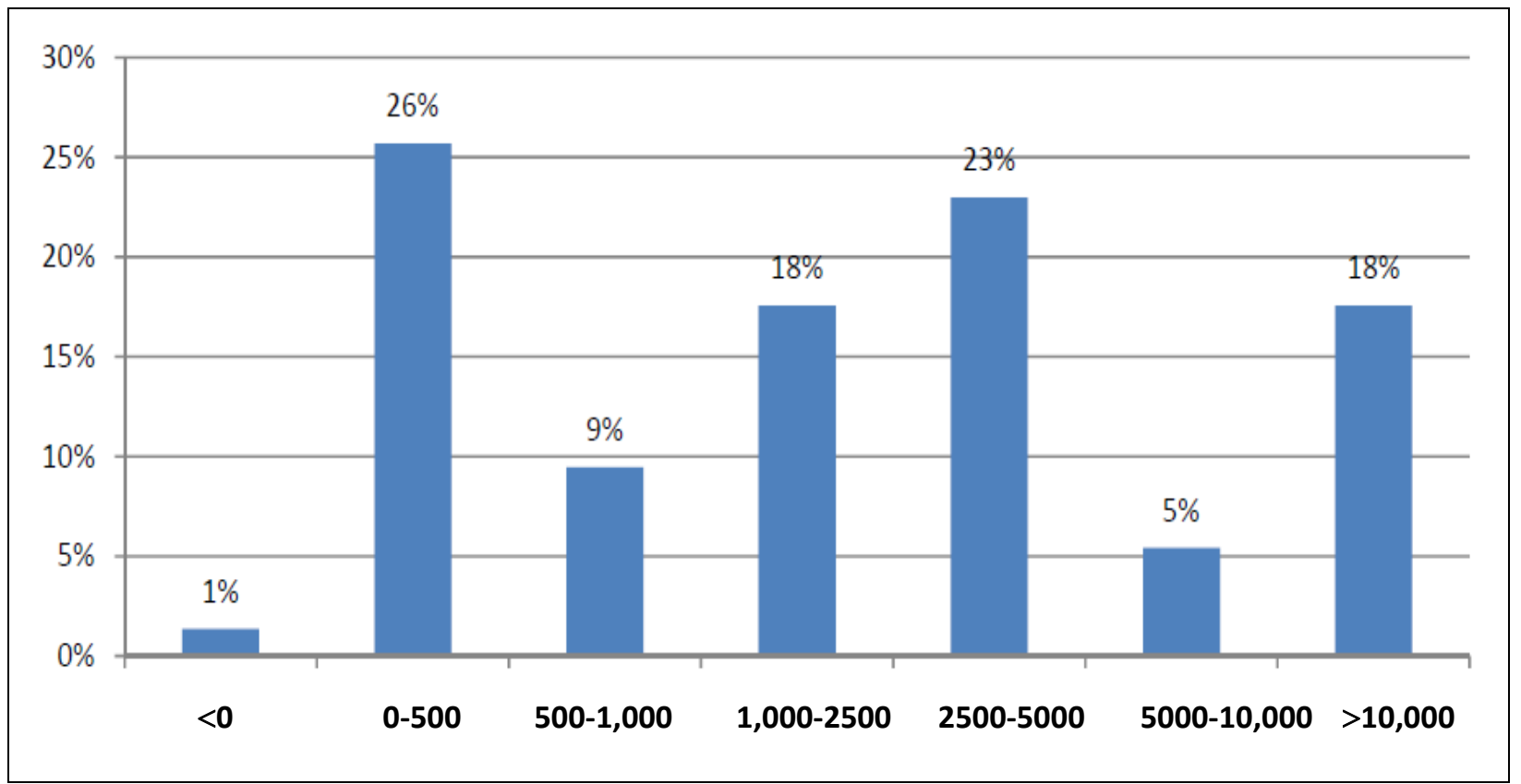

Figure 11. Distribution of the sample by classes of Net Worth $(€$, th) after four years of operating activity (personal elaboration).

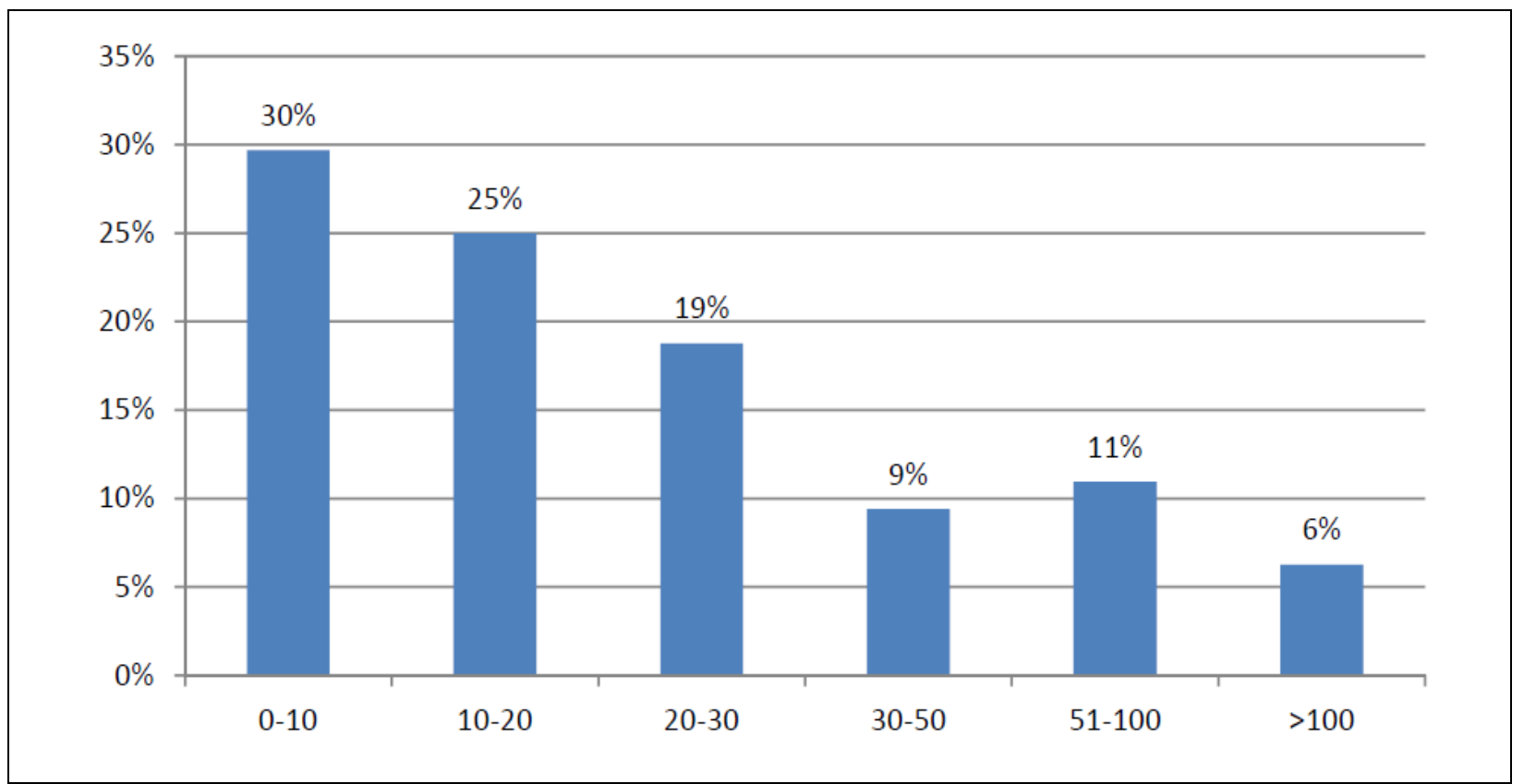

Figure 12. Distribution of the sample by classes of employees number after four years of operating activity (personal elaboration).

With reference to the first topic, the analysis carried out on the sample highlights the presence of $79 \%$ of companies characterized by having reached $(64 \%)$ or being close $(15 \%)$ to break even. This is certainly a really significant percentage, if one thinks about the ratio, usually very low, between business initiatives which overtake the first "natural selection" operated by the market and all the undertaken entrepreneurial initiatives. Furthermore, it should be noticed how this percentage increased in parallel with the gradual expansion of the 
sample, during the studies conducted by the authors ( $70 \%$ in 2006 and $75 \%$ in 2013). This evidence can be certainly explained by the economies of experience of venture capitalists, both as regards the ability to select the best companies resulting from the deal flow, and as regards the ability to create value within the participated company.

The validity and consistency of the obtained results are evidenced by numerous findings coming from the national and international academic and professional literature, where it is underlined how venture backed firms report significantly higher than average growth performance, as well as a higher level of activism in creating alliances with other companies, both technological and commercial, and a greater propensity to technological cooperation agreements with institutions belonging to the public research system.

Moving to the second order of reflections, the authors intend to provide concrete indications and, at the same time, to summarize the effects generated by the business start-up processes undertaken by companies with the contribution of a venture capitalist. In this sense, the authors proceeded to identify three significant indicators, with the aim of relating them with the amount invested by VC players. The chosen data relate to net invested capital, added value, and number of employees. This information was linked to the total amount invested by investors in the companies composing the sample. With reference to the investigated start-up deals, the evidences emerging from the analysis are the following:

- For each million Euro invested in risk capital by VC players, it is possible to detect an average investment in fixed assets of about 1.9 million at the end of the first four years of operating activity;

- Each million Euro of risk capital invested in target companies is associated with a production of an added value of approximately 0.7 million, always at the end of the first four years of operating activity;

- In terms of employment, the creation of about nine new employees can be attributed to each million Euro invested by VC players in target companies, once again at the end of the first four years of operating activity.

It seems interesting to compare these evidences with what emerged from the two similar studies conducted by the authors during 2006 and 2013, characterized by an absolutely comparable analysis, both as regards the research methodology and the economic indicators which were investigated. The difference consists only in the coordinates of the sample, which was composed in 2006 by 23 companies, while in 2013 by 40 companies.

Table 2

Final Findings and Comparison With Previous Studies (Personal Elaboration)

\begin{tabular}{|c|c|c|c|c|c|}
\hline & $\begin{array}{l}\text { Gervasoni et al. } \\
\text { (2006) }\end{array}$ & $\begin{array}{l}\text { Bollazzi \& } \\
\text { Gervasoni (2013) }\end{array}$ & $\Delta \%$ & $\begin{array}{l}\text { Current study } \\
\text { (2018) }\end{array}$ & $\Delta \%$ \\
\hline $\begin{array}{l}\text { Investments in fixed } \\
\text { assets }(*)\end{array}$ & $1.65 € / \mathrm{ml}$ & $1.5 € / \mathrm{ml}$ & $-9 \%$ & $1.9 € / \mathrm{ml}$ & $+28 \%$ \\
\hline $\begin{array}{l}\text { Production of added } \\
\text { value }\left({ }^{*}\right)\end{array}$ & $0.6 € / \mathrm{ml}$ & $0.7 € / \mathrm{ml}$ & $+16.5 \%$ & $0.7 € / \mathrm{ml}$ & - \\
\hline New employees $(*)$ & 12 units & 11 units & $-8 \%$ & 9 units & $-18 \%$ \\
\hline
\end{tabular}

Note. $(*)$ Average data in relation to an investment of one million Euro by a VC player in early stage financing investments.

The results emerged during the present study are essentially coherent with what emerged in 2006 and 2013, confirming the continuity and consistency of the benefits which result from the cooperation between 
entrepreneurs and venture capitalists. In detail, there was a slight decrease in the impact on employees and a significant increase for what concerns investments in fixed assets.

This evidence is worth of a deeper reflection. If the sample of deals is divided into two temporal subsets, the first one between 1996 and 2008 and the second one between 2009 and 2012, it is possible to detect and underline a really meaningful trend. Moving up to the most recent years, VC players have partly shifted their efforts towards industries in which the most important driver for success is represented by the possibility to invest in tangible and, in particular, intangible resources (such as patents, licenses, and so on). At the same time, some industries have changed their old framework, becoming sectors in which not only human resources are critical to be successful, but also investments in assets and technology. According to the analysis of the dataset, this is the main reason for which the impact of venture capitalists' injections of risk capital is gradually more observable in fixed assets investments than in new employment. A confirmation about this theory may be detected in the evolution of the average amount of VC investments, which has increased from 1.6 million Euro in the first period up to 2.9 million in the second one.

In conclusion, even apart from the comparison with what emerged from the previous studies, a significant social and economic impact generated by invested companies emerges clearly, which proves to be independent from the cyclical nature of an economy (as already underlined, the sample is created also with reference to phases of stagnation and recession). Therefore, if private equity in general is a pro-cyclical financial instrument which is able to accelerate development processes, venture capital establishes itself also as an anti-cyclical tool, able to act as a real "engine for development" in the economic system of a specific geographical area.

\section{Final Remarks}

The paper analyzed a relevant and representative sample of 74 early-stage VC investments in innovative start-ups, which represent all the companies for which it has been possible to collect economic information among 130 deals reported in VeM between 1996 to 2012, falling within the filter selection (a vintage year lower or equal to one). Thus, the sample covered a period spanning over 20 years and thus comprehending several different situations in the Italian economy. The operations taken into considerations were all analyzed under both the investment profile and the economic one at four years since the capital injection, in order to find information which was relevant in explaining the socio-economic impact of the investments.

The quantitative and qualitative considerations drawn from the analysis highlight how the VC activity has been able overtime to support value creation in innovative but also in traditional sectors, despite the periods of crisis and recession, as well as keeping good contributions to employment. Furthermore, the performance indicators observed, as well as the patrimonial ones, are coherent with the academic literature and the previous studies and, accordingly, they seem to prove the fundamental role of the projects selection conducted by venture capitalists.

In relation to this, future possible research studies may be involved in the comparison of this dataset with a benchmark composed by companies which are not venture backed and in a deeper sectoral analysis, in order to understand the impact of $\mathrm{VC}$ investments in different industries.

\section{References}

Ács, Z. J., Audretsch, D. B., \& Strom, R. J. (Eds.). (2009). Entrepreneurship, growth, and public policy. Cambridge: Cambridge University Press.

Audretsch, D. B. (2007). Entrepreneurship capital and economic growth. Oxford Review of Economic Policy, 23(1), 63-78. 
Audretsch, D. B., \& Keilbach, M. (2004). Does entrepreneurship capital matter? Entrepreneurship Theory and Practice, 28(5), 419-429.

Baum, J. A., \& Silverman, B. S. (2004). Picking winners or building them? Alliance, intellectual, and human capital as selection criteria in venture financing and performance of biotechnology startups. Journal of Business Venturing, 19(3), 411-436.

Bertoni, F., Colombo, M. G., \& Grilli, L. (2007). Venture capital financing and the growth of new technology-based firms: What comes first? In L. Iandoli, H. Landström, and M. Raffa (Eds.), Entrepreneurship, competitiveness, and local development (pp. 25-42). Cheltenahm UK: Edward Elgar.

Bertoni, F., Colombo, M. G., \& Grilli, L. (2011). Venture capital financing and the growth of high-tech start-ups: Disentangling treatment from selection effects. Research Policy, 40(7), 1028-1043.

Bertoni, F., Colombo, M. G., \& Quas, A. (2015). The patterns of venture capital investment in Europe. Small Business Economics, 45(3), 543-560.

Bollazzi, F., \& Gervasoni, A. (2013). Venture capital, innovative start-ups and interventions of strategic industrial policy: An empirical analisys about the Italian market. Conference proceedings of the XXV Annual Meeting of Sinergie.

Bonini, S., Alkan, S., \& Salvi, A. (2012). The effects of venture capitalists on the governance of firms. Corporate Governance: An International Review, 20(1), 21-45.

Brander, J. A., Amit, R., \& Antweiler, W. (2002). Venture capital syndication: Improved venture selection vs. the value added hypothesis. Journal of Economics \& Management Strategy, 11(3), 423-452.

Bronzini, R., Caramellino, G., \& Magri, S. (2017). Venture capitalists at work: What are the effects on the firms they finance? Bank of Italy: Temi di Discussione (Working Paper), No. 1131.

Cole, R., Cumming, D., \& Li, D. (2016). Do banks or VCs spur small firm growth? Journal of International Financial Markets, Institutions and Money, 41, 60-72.

Colombo, M. G., \& Grilli, L. (2010). On growth drivers of high-tech start-ups: Exploring the role of founders' human capital and venture capital. Journal of Business Venturing, 25(6), 610-626.

Croce, A., Marti, J., \& Murtinu, S. (2013). The impact of venture capital on the productivity of European high-tech firms: Screening or value added effect? Journal of Business Venturing, 28(4), 489-510.

Cumming, D. J., \& Fischer, E. (2012). Publicly funded business advisory services and entrepreneurial outcomes. Research Policy, 41(2), 467-481.

Cumming, D., Johan, S., \& Zhang, M. (2014). The economic impact of entrepreneurship: Comparing international datasets. Corporate Governance: An International Review, 22(2), 162-178.

Davila, A., Foster, G., \& Gupta, M. (2003). Venture capital financing and the growth of startup firms. Journal of Business Venturing, 18(6), 689-708.

Elango, B., Fried, V. H., Hisrich, R. D., \& Polonchek, A. (1995). How venture capital firms differ. Journal of Business Venturing, 10(2), 157-179.

Engel, D., \& Keilbach, M. (2007). Firm-level implications of early stage venture capital investment—An empirical investigation. Journal of Empirical Finance, 14(2), 150-167.

Gervasoni, A., \& Bollazzi, F. (2013). Impact of venture capital funding on enterprise productivity: The Italian case. Working Paper.

Gervasoni, A., \& Sattin, F. L. (2015). Private equity and venture capital. Handbook for risk capital. Milan: Guerini and Associates.

Gervasoni, A., Bollazzi, F., Del Giudice, R., \& Sartori M. (2006). Venture capital and economic development. Milan: Guerini and Associates.

Gompers, P. A., \& Lerner, J. (1999). The venture capital cycle. Cambridge: MIT Press.

Gompers, P. A., \& Lerner, J. (2004). The venture capital cycle. Cambridge: MIT Press.

Gorman, M., \& Sahlman, W. A. (1989). What do venture capitalists do? Journal of Business Venturing, 4(4), 231-248.

Guo, D., \& Jiang, K. (2013). Venture capital investment and the performance of entrepreneurial firms: Evidence from China. Journal of Corporate Finance, 22, 375-395.

Hall, J., \& Hofer, C. W. (1993). Venture capitalists' decision criteria in new venture evaluation. Journal of Business Venturing, $8(1), 25-42$.

Hargadon, A. B., \& Kenney, M. (2012). Misguided policy? Following venture capital into clean technology. California Management Review, 54(2), 118-139. 
Hellmann, T., \& Puri, M. (2000). The interaction between product market and financing strategy: The role of venture capital. The Review of Financial Studies, 13(4), 959-984.

Humphery-Jenner, M., \& Suchard, J. A. (2013). Foreign venture capitalists and the internationalization of entrepreneurial companies: Evidence from China. Journal of International Business Studies, 44(6), 607-621.

Miller, A., \& Camp, B. (1985). Exploring determinants of success in corporate ventures. Journal of Business Venturing, 1(1), 87-105.

Nahata, R. (2008). Venture capital reputation and investment performance. Journal of Financial Economics, 90(2), $127-151$.

Naudé, W. (2010). Entrepreneurship, developing countries, and development economics: New approaches and insights. Small Business Economics, 34(1), 1.

Oe, A., \& Mitsuhashi, H. (2013). Founders' experiences for startups' fast break-even. Journal of Business Research, 66(11), 2193-2201.

Romain, A., \& van Pottelsberghe, B. (2003). The economic impact of venture capital. Brussels, Belgium: Solvay Business School.

Samila, S. (2012). Regional impact of venture capital. In The Oxford Handbook of Venture Capital. doi:10.1093/oxfordhb/9780195391596.013.0027

Sanders, W. M., \& Boivie, S. (2004). Sorting things out: Valuation of new firms in uncertain markets. Strategic Management Journal, 25(2), 167-186.

Vesper, K. H. (1993). New venture mechanics. Upper Saddle River, New Jersey: Prentice Hall.

Wang, J., Wang, J., Ni, H., \& He, S. (2013). How government venture capital guiding funds work in financing high-tech start-ups in China: A "strategic exchange" perspective. Strategic Change, 22(7-8), 417-429.

Wang, L., \& Wang, S. (2012). Economic freedom and cross-border venture capital performance. Journal of Empirical Finance, 19(1), 26-50.

World Bank. (2004). World Bank group support for small business. Washington, DC: World Bank. 